\title{
New records of the striped cleaner shrimp Lysmata grabhami (Gordon, 1935) from Brazil, Southwestern Atlantic
}

\author{
A. D. Kassuga ${ }^{a, b *}$, K. Diele ${ }^{c}$ and M. Hostim-Silva ${ }^{a}$ \\ aPrograma de Pós-Graduação em Oceanografia Ambiental, Base Oceanográfica, Universidade Federal do Espirito Santo - \\ UFES, Rodovia ES 10 565, Coqueiral de Aracruz, CEP 29199-970, Aracruz, ES, Brazil \\ ${ }^{\mathrm{b}}$ Laboratório de Biotecnologia Marinha, Departamento de Biologia, Instituto de Estudos do Mar Almirante Paulo Moreira \\ - IEAPM, Rua Kioto, 253, Praia dos Anjos, CEP 28930-000, Arraial do Cabo, RJ, Brazil \\ ${ }^{\mathrm{c} S}$ School of Life, Sport and Social Sciences, Edinburgh Napier University, Edinburgh, EH11 4BN, UK \\ *e-mail: kassuga@gmail.com
}

Received: February 19, 2014 - Accepted: August 3, 2014 - Distributed: November 30, 2015

(With 2 figures)

\begin{abstract}
New records for Lysmata grabhami (Gordon, 1935) in Brazilian waters are presented. Four adult individuals from coastal waters off the city of Vitória, Espírito Santo coast and one adult from Trindade Island were collected during scuba diving in depths between 20-40 meters. These two records represent the southernmost published finding of this species in the Atlantic and the record for Vitória, Espirito Santo is the first from Brazilian coastal waters.
\end{abstract}

Keywords: Decapoda, Hippolytidae, Espírito Santo, Trindade Island, distribution range.

\section{Novos registros do camarão limpador Lysmata grabhami (Gordon, 1935) no Brasil, Atlântico Sul Ocidental}

\section{Resumo}

Novos registros de ocorrência de Lysmata grabhami (Gordon, 1935) em águas brasileiras são apresentados. Quatro indivíduos foram coletados próximo à costa da cidade de Vitória, Espírito Santo, e um na Ilha da Trindade, por mergulhadores autônomos em profundidades entre 20-40 metros. O presente registro é a ocorrência mais meridional conhecida para esta espécie no Atlântico e o registro em Vitória é o primeiro para águas costeiras brasileiras.

Palavras-chave: Decapoda, Hippolytidae, Espírito Santo, Ilha da Trindade, distribuição.

\section{Introduction}

The family Hippolytidae is composed of 37 genera, with 338 described benthic shrimp species (De Grave and Fransen, 2011). Most of them dwell in shallow tropical waters and are associated with seagrass or reef environments (Bauer, 2004). Forty-two species belong to the genus Lysmata Risso, 1816 (De Grave and Fransen, 2011), 14 of which are known to occur in the Atlantic Ocean (Rhyne and Lin, 2006; Soledade et al., 2013). The genus contains several so called cleaner shrimp species that are highly valued by the marine ornamental trade, due to their striking coloration, little aggressiveness and interesting cleaning behavior (Calado et al., 2003). Extensive exploitation of these shrimps poses a strong pressure on their populations to supply the multimillion-dollar trading industry (Wabnitz et al., 2003). Knowledge of their distribution and habitats, reproductive biology and ecology is of great importance to support preservation and maintenance of wild populations.

Lysmata grabhami (Gordon, 1935), also known as the scarlet striped cleaner shrimp, is a monogamous

species (Wong and Michiels, 2011) that inhabits rocky and reef environments, from 3 to 55 meters water depth, in the eastern and western Atlantic (Manning and Chace Junior, 1990). It has been recorded from around Madeira Island (type-locality), Ascension Island and in the western Atlantic in Bermuda, Gulf of Mexico, Florida Keys, Bahamas, Antigua and Barbuda Island, Bonaire, Lesser Antilles and the oceanic waters of the north of South America (i.e. the Brazilian oceanic islands of Saint Peter and Saint Paul Archipelago as L. amboinensis (De Man, 1888), (Gordon, 1935; Holthuis et al., 1980; Manning and Chace Junior, 1990; Wicksten, 1995; Chace Junior, 1997). A first indication that this species may also occur in coastal Brazilian waters is given by Gasparini et al. (2005), who analyzed the marine ornamental trade in Brazil using the Global Marine Aquarium Database (GMAD). Based on this database, the authors included L. grabhami in a list of invertebrates exported from Brazil. However, the presence 
of the species in Brazilian coastal waters has not yet been scientifically confirmed.

In this paper, we aim to register new occurrences of L. grabhami in the southwestern Atlantic. We also report the morphological variation observed in our specimens in order to improve the knowledge on the taxonomical characters of this species.

\section{Material and Methods}

Individuals of the striped cleaner shrimp were collected while scuba diving in two different locations. Four individuals were collected in coastal waters off the city of Vitória, Espírito Santo, Brazil (20²1'20" S, $40^{\circ} 14$ ' 40" W) in June 2012 by professional ornamental fishermen, over rocky bottom at a depth of 40 meters. At Trindade Island, Brazil (202 $28^{\prime} 24^{\prime}$ ' S, $\left.29^{\circ} 20^{\prime} 26^{\prime \prime} \mathrm{W}\right)$, one individual was collected in 2009 at a depth of $20 \mathrm{~m}$. Measurements were made with a digital caliper, to the nearest $0.1 \mathrm{~mm}$, from the specimen from Trindade and one specimen from Vitória. The other three individuals were kept alive in aquaria. The two analyzed individuals were placed in the Coleção Carcinológica do Laboratório de Carcinologia da Universidade Federal do Rio de Janeiro under the numbers 4953 and 4954.

\section{Results and Discussion}

According to Gordon (1935), Lysmata grabhami has a short rostrum, scarcely reaching the distal end of the second antennular segment, its rostral formula is. The antennal scale is short and has almost the same size as the antennular peduncle. The carpus of the second pereopod is subdivided in 17-23 segments and the merus in seven segments; in the pereopods 3-5 each propodus is armed with a ventral series of 10-15 short spines, each carpus presents 2-5 ventral spinules and each merus 2-5 spines on the outer surface.

The specimens examined here have short rostra and the rostral formula is. The antennal scale barely reaches the distal end of the antennular peduncle. The carpus of the second pereopod is subdivided in 18-23 segments and the merus in seven segments; in pereopod 3 the propodus has a series of 11-15 ventral spines, the carpus has 6-7 ventral spinules and merus has 5 spines on the outer surface; in pereopod 4 the propodus has a series of 11 ventral spines, the carpus has 6 ventral spinules and the merus has 3 spines on the outer surface; in pereopod 5 the propodus has a series of 11 ventral spines, the carpus has 7 ventral spinules and the merus has 2 spines on the outer surface. The morphology of the specimens agrees with the species description presented by Gordon (1935). However, some variation in the rostral formula, in the segmentation of the carpus of the second pereopod and in the number of spinules on the carpus of pereopods 3-5 was observed. The striking coloration of this species (see Figure 1) distinguishes it from any other congeneric species reported from Brazilian waters, which are pale colored with fine red lines throughout the body. Apart from its coloration, this species can easily be differentiated from other Brazilian species from the genus Lysmata by its short antennal scale, which barely reaches the third segment of the antennular peduncle, while in all other species the antennal scale is long and clearly overreaches the antennular peduncle.

Some confusion regarding the status of this species has been reported in the literature. Hayashi (1975) synonymized L. grabhami with the Indo-Pacific L. amboinensis, and considered it as one of the few circumtropical shrimps. However, minor differences in coloration between these two taxa were considered as constant enough to justify the original separation into two species (Manning and Chace Junior, 1990; Chace Junior, 1997). Lysmata grabhami presents a continuous middorsal white stripe from the tip of the rostrum to the end of the telson and the outer border of the uropodal exopods is also white (Figure 1). In contrast, the middorsal white stripe of $L$. amboinensis is interrupted at the end of the sixth abdominal somite and the anterior third of the telson, while the lateral branch of each uropodal exopod presents one proximal and one distal white spot (see Baeza, 2010, p. 263, Figure 3). Thus, the color pattern of the specimens agrees with the coloration pattern described for L. grabhami. More recently,
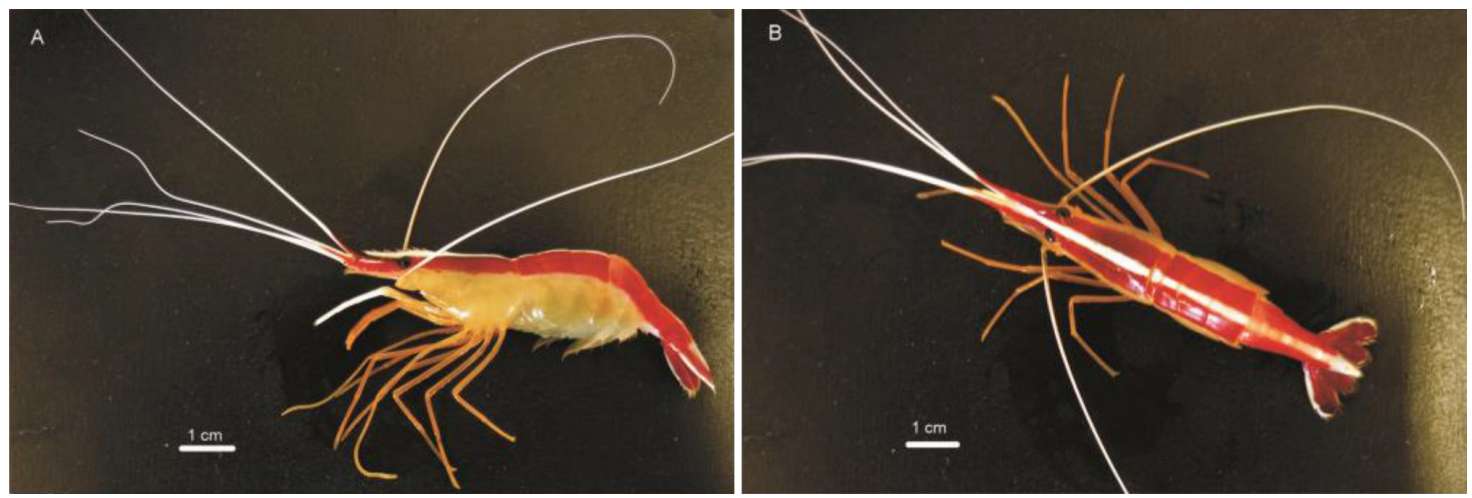

Figure 1. Lysmata grabhami (Gordon, 1935) from Vitória, Espírito Santo, Brazil. (A) Lateral view; (B) dorsal view. Photo: Alexandre D. Kassuga. 


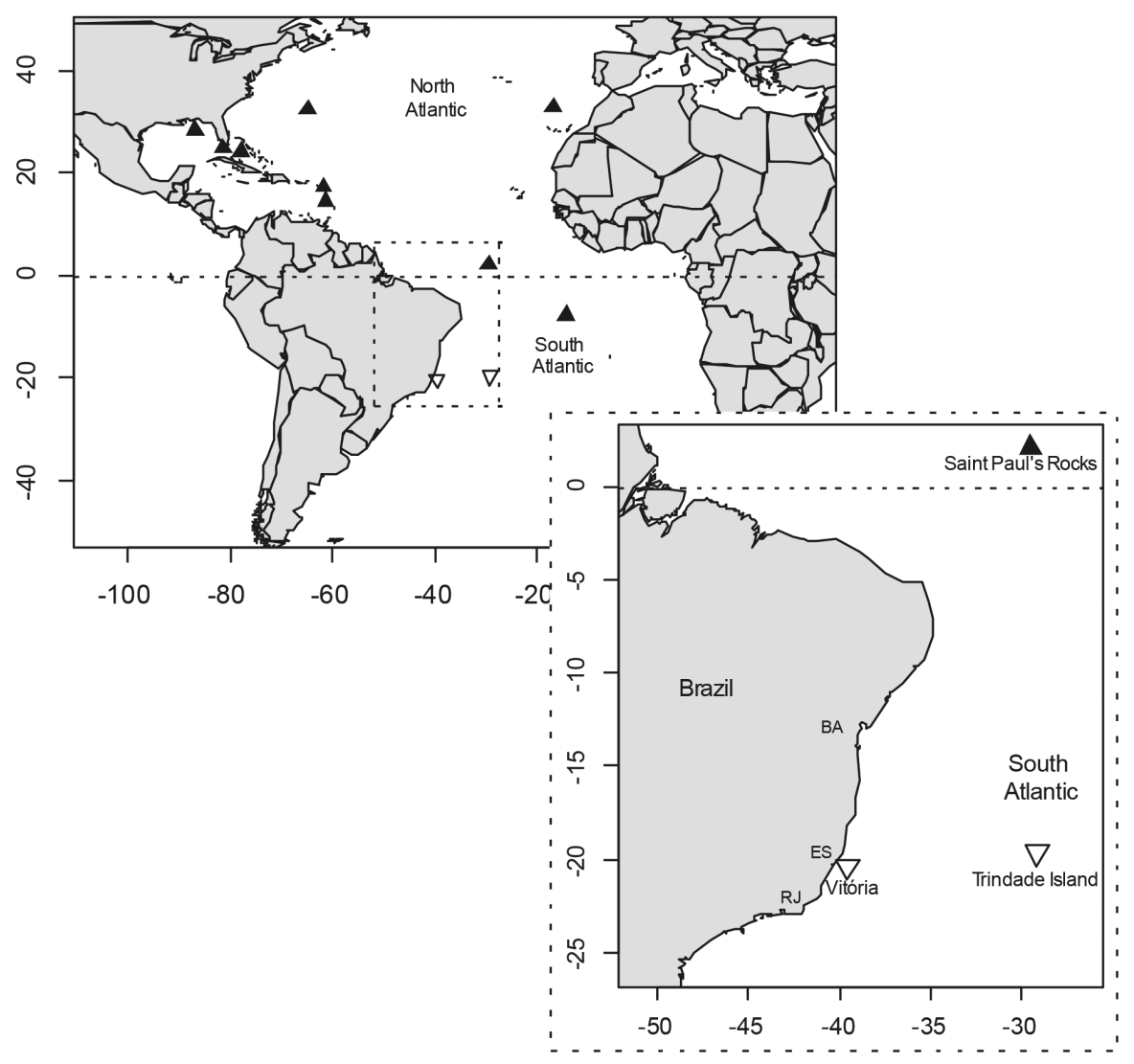

Figure 2. Current distribution of Lysmata grabhami (Gordon, 1935). ( $\mathbf{\Delta}$ ) Previous records; $(\nabla)$ new records. BA - Bahia State; ES - Espírito Santo State; RJ - Rio de Janeiro State.

a molecular phylogenetic analysis of the genus Lysmata showed that although very closely related, they should indeed be considered as two valid species (Baeza, 2010).

\section{Conclusion}

The two new locations of Lysmata grabhami occurrence in Brazil, i.e. coastal waters in Espírito Santo and oceanic waters near Trindade Island, extend the known distribution of this highly priced ornamental species (Figure 2). It is the first time this species is described from coastal Brazilian waters, and our results extend the registered distribution of this species more than $1400 \mathrm{~km}$ southward compared to its previously known geographical distribution (Saint Paul and Saint Peter Archipelago).

\section{Acknowledgements}

The authors thank Dr. Rafael Maciera and MSc. Thiony Simon for the collection of the individual from Trindade Island; also, MSc. Maik da Hora Cividanes for helping with contacts with the fisherman. This research was granted by FAPES. Karen Diele received funding from the MASTS pooling initiative (The Marine Alliance for Science and Technology for Scotland) and its support is gratefully acknowledged. MASTS is funded by the Scottish Funding Council (grant reference HR09011) and contributing institutions.

\section{References}

BAEZA, J.A., 2010. Molecular systematics of peppermint and cleaner shrimps: phylogeny and taxonomy of the genera Lysmata and Exhippolysmata (Crustacea: Caridea: Hippolytidae). Zoological Journal of the Linnean Society, vol. 160, no. 2, pp. 254-265. http:// dx.doi.org/10.1111/j.1096-3642.2009.00605.x.

BAUER, R.T., 2004. Remarkable shrimps: adaptations and natural history of the carideans. Norman: University of Oklahoma Press. 282 p. Animal History Series, vol. 7.

CALADO, R., LIN, J., RHYNE, A.L., ARAÚJO, R. and NARCISO, L., 2003. Marine ornamental decapods: popular, pricey, and poorly studied. Journal of Crustacean Biology, vol. 23, no. 4, pp. 963-973. http://dx.doi.org/10.1651/C-2409.

CHACE JUNIOR, F. A., 1997. The Caridean Shrimps (Crustacea: Decapoda) of the Albatross Philippine Expedition, 1907-1910, Part 7: Families Atyidae, Eugonatonotidae, Rhynchocinetidae, Bathypalaemonellidae, Processidae, and Hippolytidae. Smithsonian Contributions to Zoology, vol. 587, pp. 1-106.

DE GRAVE, S. and FRANSEN, C.H.J.M., 2011. Carideorum Catalogus: the recent species of the dendrobranchiate, stenopodidean, 
procarididean and caridean shrimps (Crustacea: Decapoda). Zoölogische Mededeelingen, vol. 85, no. 9, pp. 195-588.

GASPARINI, J.L., FLOETER, S.R., FERREIRA, C.E.L. and SAZIMA, I., 2005. Marine ornamental trade in Brazil. Biodiversity and Conservation, vol. 14, no. 12, pp. 2883-2899. http://dx.doi. org/10.1007/s10531-004-0222-1.

GORDON, I., 1935. On new or imperfectly known species of Crustacea Macrura. Journal of the Linnean Society of London Zoology (Jena, Germany), vol. 39, no. 266, pp. 307-351. http:// dx.doi.org/10.1111/j.1096-3642.1935.tb00075.x.

HAYASHI, K.-I., 1975. Hippolysmata grabhami (Gordon), a synonym of Lysmata amboinensis (De Man) (Decapoda, Caridea, Hippolytidae). Publications of the Seto Marine Biological Laboratory, vol. 22, no. 5, pp. 285-296.

HOLTHUIS, L.B., EDWARDS, A.J. and LUBBOCK, H.R., 1980. The decapod and stomatopod crustacean of St Paul's Rocks. Zoölogische Mededeelingen, vol. 56, no. 3, pp. 27-51.

MANNING, R.B. and CHACE JUNIOR, F.A., 1990. Decapod and Stomatopod Crustaceans from Ascension Island, South Atlantic Ocean. Washington: Smithsonian Institution Press. 91 p. Smithsonian Contributions to Zoology, no. 503. http://dx.doi. org/10.5479/si.00810282.503.
RHYNE, A.L. and LIN, J., 2006. A western Atlantic peppermint shrimp complex: redescription of Lysmata wurdemanni, description of four new species, and remarks on Lysmata rathbunae (Crustacea: Decapoda: Hippolytidae). Bulletin of Marine Science, vol. 79, no. 1 , pp. $165-204$.

SOLEDADE, G.O., BAEZA, J.A., BOEHS, G., SIMÕES, S.M., SANTOS, P.S., COSTA, R.C. and ALMEIDA, A.O., 2013. A precautionary tale when describing species in a world of invaders: morphology, coloration and genetics demonstrate that Lysmata rauli is not a new species endemic to Brazil but a junior synonym of the indo-pacific L. vittata. Journal of Crustacean Biology, vol. 33, no. 1, pp. 66-77. http://dx.doi.org/10.1163/1937240X-00002122.

WABNITZ, C., TAYLOR, M., GREEN, E. and RAZAK, T., 2003. From ocean to aquarium: the global trade in marine ornamental species. Cambridge: UNEP/WCMC.

WICKSTEN, M., 1995. Associations of fishes and their cleaners on coral reefs of Bonaire, Netherlands Antilles. Copeia, vol. 2, no. 2, pp. 477-481. http://dx.doi.org/10.2307/1446914.

WONG, J.W.Y. and MICHIELS, N.K., 2011. Control of social monogamy through aggression in a hermaphroditic shrimp. Frontiers in Zoology, vol. 8, no. 30, pp. 1-7. PMid:22078746. 